\title{
Omphile and his Soccer Ball: Colonialism, Methodology, Translanguaging Research
}

\author{
By Finex Ndhlovu
}

University of New England, Australia

Email: fndhlovu@une.edu.au

In this paper, I am reviewing autoethnographic method in translanguaging research. I tell a story that is based on a casual and unplanned encounter with Omphile, a seven year old boy with whom I interacted using communicative practices that confirmed the suppositions of translanguaging theory but also challenged the methods that support empirical observations of translanguaging research-in equal measure. The paper signposts the promises that autoethnographic approaches hold for researching naturalistic human communication in ways that side step the language and methods of the positivist tradition. I argue that in the same way that contemporary sociolinguistics theorisations remind us about how communication is not limited to determinate languages or codes, research does not have to be limited to controlled, systematic scientific methods. The framework of autoethnography reviewed in this article is one example of a praxis that is antimethodological and, thus in line with many of the anti-foundational premises of translanguaging theory.

Key words: translanguaging, research methodologies, autoethnography, experimental research designs, researcher-as-participant, linguistic systems, translingual practices, linguistic ideologies

\section{Framing the problem}

Scholars of sociolinguistics and allied disciplines have made quite commendable theoretical and conceptual progress when it comes to challenging linguistic normativity and those frameworks that have crystallised into some kind of traditional orthodoxy in language research. Such progress is attested by the burgeoning of theorisations around language as process, dating back to the 1970s and 1980s work of Einar Haugen, Lachman Khubchandani, John J. Gumperz and Howard Giles. By the 1990s the cacophony of voices following this line of critique had grown, with Lachman Khubchandani (1997) proposing what he called "plurality of consciousness" and "communication ethos", which are about consideration of how individual language users have "dayto-day, moment-to-moment successes that make language transactive, functional and 
alive" (Khubchandani, 1997: 14). This was a call to shift the locus of enunciation and see language as an ongoing process of social transaction and not something that is located in an institution.

The critique of conventional understandings of language has continued to gather momentum in recent times with the emergence of quite contemporary theories such as 'transidiomatic practice' (Jacquemet, 2005), 'polylanguaging' (Jørgensen 2008, 2010), and 'codemeshing' (Canagarajah, 2011). 'Translanguaging' (García 2009; García \& Li Wei 2013; García \& Kleyn, 2016) and 'metrolingualism' (Pennycook \& Otsuji, 2015) are the latest additions to the long list of contemporary sociolinguistic theorisations. These theories echo Blommaert, Leppänen, Pahta and Räisänen's (2012: 18) advice on the need to start with our "feet on the ground from a strong awareness that the phenomenology of language in society has changed, has become more complex and less predictable than we thought was." A crucial foundational premise shared by these theoretical frameworks is their call for unbounding language from its position as an object of study and situating it in the sociocultural complexity that surrounds speakers' 'real language use' (Ndhlovu 2015).

What also unites the majority of followers of this scholarly tradition-in a rather negative way-is their reliance on conventional research methodologies that are limited to controlled scientific experiments: oral interviews, surveys, focus groups, participant observations, and so on. This article argues that notwithstanding the theoretical and conceptual innovations that have been made, there is a gap that is yet to be filled in contemporary sociolinguistics research. This is about doing research using methodologies that are consistent with the anti-foundational stance of emerging theories such as translanguaging.
Current conventional scientific methods and the language they use have rarely been challenged or problematised. This invites several questions centring on the ways sociolinguists continue to be wedded to conventional methodologies in language research. If we recognise that the phenomenology of language is so complex and that the ways human beings communicate eschew any easy generalisations, why do we still do research using the same conventional methods that are used to investigate languages as ordered and enumerable objects?

How realistic is it for new philosophies of language to claim they are pushing scholarship forward in a new direction when their theoretical suppositions are supported by data generated through conventional research methods? How do we do ethnographic social science research in ways that allow us to capture the complex relations between society and communication resources? In other words, can we really claim to be theorising in unconventional ways when our methodologies remain conventional? I address these questions by narrating and analysing a story that is based on my casual and unplanned encounter with Omphile, a seven year old boy whose communicative practices prompted me to think more critically about widely used methods in social science research.

The style of presentation I use departs slightly from conventional academic narrative techniques in that it does not have the usual elements of a research essay such as research methods and procedures, research design, sampling techniques, and so on. This is because the article is a reflective piece that reports on a random unplanned observation of naturallyoccurring communicative practices. The paper, is therefore, in in line with the frameworks of autoethnography, which is "narrative research that entails a double narrative process, one that 
includes the narratives generated by those participating in the research, and one that represents the voice of the researcher as narrator of those narratives" (Kratzis \& Green 1997 cited in Méndez 2013: 280). Additionally, the central themes of the analysis align with debates around reflexivity in ethnomethodology (Watson 2005, Colombo 2003, Czyzewski 1994) and approaches of conversational analysis that elucidate basic aspects of human sociality that reside in talk (Mazeland 2006, Heritage 1995, Atkinson \& Heritage 1984). I discuss autoethnography in greater detail in a later section with an eye on prospects and possibilities for enriching translanguaging research methodologies. I also make in the same section some passing remarks on the relevant theoretical and methodological insights of reflexivity and conversational analysis to support my argument that the things that we know so foundationally as 'languages' are not as straight forward as they are thought to be. But first I would like to narrate the story of my encounter with Omphile.

\section{Encounter with translingual Omphile}

In August 2016, I attended the Third International Conference on Language and Literacy Education that was organised and hosted by the Wits School of Education at Witwatersrand University in Johannesburg, South Africa. In the afternoon of Day Two there were three parallel sessions themed 'Translanguaging Lesson Demonstrations'. Although I had a very keen interest in seeing what a translanguaging lesson would look like, I was underwhelmed by the so-called translanguaging lessons that were not different at all in form and content to the traditional bilingual or dual medium of instruction demonstrations. The translanguaging lesson demonstrations reinforced a view of languages as fixed and bounded objects that are separate from each other-supposedly because the presenters' misunderstood translanguaging pedagogy. Owing to my frustration over the 'translanguaging lesson' demonstrators' limited understanding of what the theory and praxis of translanguaging is all about, I decided to slip out of the conference venue and took a short walk around the Parktown Campus of Wits University. I then sat on a chair on one of the campus courtyards, reading the conference programreflecting on how some scholars were missing the crucial message of translanguaging theory. Little did I know that this was, in fact, going to be an opportunity for me to witness conversational practices that would prompt me to analyse contradictions between contemporary sociolinguistics theorisations and the methods used to collect data that support such theoretical positions.

While sitting on the chair, I saw this little boy coming from the other end of the campus kicking a soccer ball and seemingly unbothered by the few cars that drove past. As he got closer to me he slowed down his pace of walking and kicking the ball. He then stopped and greeted me using the honorific Setswana/ Sepedi greeting 'Dumelang' (literally: plural form for 'hello') to which I replied using the singular form 'Dumela, ukae?' (literally: singular form for 'hello, how are you?').

The rest of our conversation, in multiple languages that we both moved in and out of, subconsciously, went as follows $(\mathrm{M}=$ me; $\mathrm{O}=$ Omphile):

M: (speaking in isiZulu) 'Ungubani igama lakho?' (What is your name?)

O: (with a little smile): 'Omphile'.

M: (speaking in isizulu) 'Kutheni udlala wedwa?' (Why are you playing alone?) 
O: (speaking in isiZulu) 'Anginaye ubhuti noma usisi. Ngihlala nogogo' (I do not have any brother or sister that I can play with. I live with my grandmother).

O: (this time around mixing isizulu and Setswana expressions) 'Wena awunaye umosimane? (Don't you have a son?)

M: (mixing isizulu and English expressions): 'Nginaye but umkhulu kakhulu, unaseventeen' (I do have a son but he is big, he is seventeen).

O: (looking at me with a sullen face and gasping a sigh of great disappointment) 'Ah! ngibe ngisithi mhlawumbe ungangami, ngifuna adlale nami' ( Oh, no! I thought he was of my age, I would have wanted him to play with me) .

Based on this last statement, I came to realise that my new-found friend, Omphile, really wanted someone to play with. So, I offered to kick the soccer ball with him to which he jumped with a lot of excitement and declared from start (again using a mixture of expressions from isizulu, Setswana, Sepedi and English) that he was going to beat me. So, we quickly identified some temporary goal posts and started kicking the ball. After about five minutes of play he had scored three goals while I had zero. Each time he scored he would jump up and down in excitement, declaring in isizulu, Sepedi, Setswana and English that he was a very good soccer player and that I was never going to beat him. It was, indeed, a lot of fun until after I temporarily caught up with him by scoring three goals, thus making it a draw.

We continued playing, with Omphile really determined to prove that he was unbeatable. He eventually scored two more goals, which was a very big win for him. I kept on trying hard but I could not catch up with him. So, in the end I gave up; he still wanted to keep on playing but I had to go back to the conference venue. In order to bring the game to an end, I admitted that he was the winner and gave him a few coins as a way of conceding defeat. The soccer game eventually came to an end after 20 to 25 minutes of play.

So, what is the point of this story? It is not so much about me meeting a seven year old boy and playing soccer with him. Two things are of significance here: (i) the dynamic of our interaction, the ways in which we negotiated and deployed our respective linguistic systems; and (ii) the methodological implications of my empirical observations that were not based on pre-planned approaches of the scientific method. It is evident that the interaction I had with Omphile and the attendant language practices confirmed both the theoretical suppositions and empirical observations of previous sociolinguistics scholarship described in the first and second paragraphs of this article. The soccer game itself was in many ways a form of language; an integral part of the discourse and praxis of communication in naturally-occurring environments. As the literature on conversational analysis has posited, single acts are parts of larger, structurally organised entities, also known as sequences (Schegloff 2006). The most basic and quite important sequences consist of actions performed by one interactant, which invite particular types of further actions performed by another interactant; and so on. The actions can be vocal (as in question-answer, greeting-greeting, invitation-acceptance/ declination) or performative (as in gestures or partaking in an activity of mutual interest) (Schegloff 2006). My interaction with Omphile consisted of all of these. Furthermore, consistent with the suppositions of reflexivity, the soccer game in particular was a constituent part of communicative practice I am describing here and, therefore, elaborates the circumstances of our interaction and 
conversation while simultaneously being elaborated by them (Watson 2005: 7)

Another equally important point that is at the core of this paper is about how my empirical observations were made outside the orbit of mainstream social science methodologies - thus tying in with the tenets of the anti-conventional agenda. I did not go out with a preplanned research idea built around a scientific experimental design that sought to address some pre-conceived research questions. Neither Omphile nor I did at any one point attempt to raise the question about which named language(s) each one of us could speak well as a way of establishing common ground (Goffman 1981; Enfield 2008) in our interaction. We did not even bother to find out whether there was any named language that we had in common. From the very start of our conversation, we tapped into our respective linguistic systems that emerged naturally and spontaneously during the course of our interaction. Although my knowledge of Setswana and Sepedi is quite limited, I did not alert Omphile to this when he passed a greeting in these languages. Neither did I ask him about his level of knowledge of both isizulu and English, the other two languages that contributed to the linguistic systems that we used throughout the course of our interaction.

Another notable point is one about the blurring or porosity of language boundaries that was evident in my conversation with Omphile. We both crossed effortlessly-and even disregarded - the supposed language boundaries as we used linguistic resources available to us in rather seamless and fluid ways. This laid to rest notions of linguistic purism whereby languages are perceived as distinctly bounded entities that are to be used in particular ways. Though named languages are real and exist in societies that have coined names for them, "they do not necessarily overlap with the linguistic systems of individual speakers" (García and Kleyn 2016: 10). This is precisely what we see in my conversation with Omphile. The linguistic usages and interactional processes between Omphile and me are a clear example of communicative translanguaging that does not necessarily follow pre-conceived boundaries of languages-with-names. But in what ways does the story of my encounter with Omphile confirm the theoretical suppositions of contemporary sociolinguistic theorisations? And what does this story tell us about how to do research on language and communication in ways that enable us to observe and report on those casual naturally-occurring conversational data that escape the attention of conventional scientific methods? I address these and related questions in the remaining parts of this article.

\section{An appraisal of translanguaging and allied theories}

Translanguaging is one of the most recent theories of language and communication that seek to contribute a more nuanced conceptualisation of how real people communicate in everyday real life. A common definition of translanguaging is one provided by García and Kleyn (2016: 14):

[T]ranslanguaging refers to the deployment of speakers' full linguistic repertoire, which does not in any way correspond to the socially and politically defined boundaries of named languages.

García and Kleyn further suggest a bifurcated view of translanguaging the weak version and the strong version. The weak version of translanguaging is one that supports named language boundaries, and yet calls for the softening of these boundaries. This view, which follows hard on the heels 
of traditional sociolinguistic notions of 'code-switching', and 'code-mixing' is associated with the work of Suresh Canagarajah (2011) on 'code-meshing' and Jim Cummins' (1979 \& 2007) 'interdependence hypothesis' and 'transfer theories'. On the other hand, the strong version of translanguaging, which I also subscribe to, posits that bilingual people do not speak languages, but rather use their repertoire of linguistic features selectively. Seen from a translanguaging perspective, 'language' is not something that a speaker simply 'has' but a repeated and expansive system of communicative practices in which he or she continuously engages (García 2009; García \& Li Wei 2013; Canagarajah 2011; and Li Wei \& Zhu Hua 2013). Translanguaging, thus, becomes a summary term that should be taken in the sense of "transcending" or going beyond the two or more named languages of bi-/multilinguals (García and Kleyn 2016: 10). In this regard, it converges with other quite contemporary scholarly conversations that promote and value language as local practice (Pennycook 2010); languages as creative linguistic practices (Otsuji \& Pennycook 2010); languages as plurilingual multimodal communication resources (Piccardo 2013); and languages as communicative resources (Blommaert 2010). The main argument of these studies is that boundaries between languages are somewhat temporal, porous and irrelevant if we consider the dynamic, unpredictable and spontaneous ways by which people use language as a social practice (Ndhlovu 2015). This body of work begins the movement away from didactic thinking about language and how human beings communicate. However, the key point here is that although translanguaging and similar theories challenge linguistic normativity and push the debate on language theorisation towards an antifoundational direction, they still rely on the traditional scientific method of data collection. Attempts to transcend conventional scientific methods in most translanguaging reports have remained somewhat tentative and parsimonious as most such studies continue to rely on focus groups, oral interviews, and ethnography (in the traditional sense of 'researcher as impartial observer').

As the relevant body of literature dating back to the early 1970 s has clearly demonstrated, the idea of language as object is a modernist and colonial invention that does not capture the complex communicative practices of the majority of people around the world (see for example, Haugen 1972; Gumperz 1982; Giles 1984 and Khubchandani 1997). Here is how Einar Haugen, way back in 1972, expressed his frustration with mainstream sociolinguistics theorisations: "The concept of language as a rigid, monolithic structure is false, even if it has proved to be a useful fiction in the development of linguistics. It is the kind of simplification that is necessary at a certain stage of a science, but which can now be replaced by more sophisticated models" (Haugen 1972: 325). This line of argument has been pursued further in more recent times by scholars such as Sinfree Makoni and Alastair Pennycook (2007), Jan Blommaert (2010), Lesley Milroy (2001) and many others.

These scholars argue that the emergence of modern linguistics as a social science at the dawn of the twentieth century was prompted by fundamental questions around the relationship of language, thought, cognition, and how human beings interact with one another and with their immediate environment. Some well-known pioneering thinkers such as Ferdinand de Saussure, Leonard Bloomfield, Noam Chomsky, and those who followed their tradition of linguistics tried to address these issues in their work. However, they did so from a segregationist/colonial perspective, which has come to be known as orthodox/ 
mainstream linguistics. Segregationists treat "language and languages as objects existing in their own right, independently of other varieties of communication" (Harris 1987: 131). Such insistence on the study of language structure rather than the study of linguistic communities or communities of practice is consistent with the approaches of colonial linguistics that sought to homogenise what were otherwise disparate communities to facilitate colonial domination and control (Makoni 1998; Brutt-Griffler 2006; Ndhlovu 2010; and Errington 2008).

Therefore, the rise of the translanguaging school of thought is a welcome development not because it is a novelty. Rather it has to be seen as symptomatic of homecoming by academics and education practitioners. It signals a re-awakening and a reconnection with the foundational questions of language in society - those basic questions around how human beings communicate. The renewed interest in understanding the complex communicative practices of pluringual and translingual individuals is essentially about bringing back to mainstream academic conversations an important issue that had been overlooked and marginalised following the rise of modernist theories of language that have erroneously come to be seen as if they were of a 'natural kind'. So, essentially, translanguaging is about going back to basics.

The majority of scholars who have exercised their minds on the theory and praxis of translanguaging have done so in the context of educational linguistics - in language education classroom contexts, second language acquisition, bilingual education, TESOL education, and so on (see for example, García 2009; Canagarajah 2011 \& 2013; Cummins 1979 \& 2007; García and Li Wei 2014; Creese and Blackledge 2010; and Hornberger and Link, 2012). The flourishing of translanguaging theorisation in educational settings is perfectly understandable given that the roots of this theory actually lie in Cen Williams' (1994) doctoral thesis that explored opportunities presented by the presence of bilingual children in Welsh school classrooms (García \& Kleyn 2016). Some other scholars have, however, theorised and tested the applied interests of translanguaging in out-of-classroom contexts. For example, Li Wei (2011) and Li Wei and Zhu Hua (2013) use the insights of translanguaging theory to investigate transnational identities and ideologies of Chinese university students in the UK. Li Wei and Zhu Hua (2013: 516) use narrative data and ethnographic observations of Britishborn Chinese students (whose parents came from China, Taiwan, Hong Kong and Singapore) to "explore issues such as their socio-cultural identification processes, the interactions between their linguistic and political ideologies, their multilingual practices and what they have learned from being part of this new [transnational] social space." Li Wei and Zhu Hua (2013) conclude by highlighting the promises of translanguaging theory in the context of identity studies. They point out that the "translanguaging approach has the capacity to demonstrate how multilayered social, linguistic and community practices and reflections yield multipleness in identity construction. The story of my encounter with Omphile described above adds another dimension to the theory and praxis of translanguaging, that of communicative translanguaging. What we see from the moments of interaction between Omphile and myself are instantiations of linguistic boundary crossing that take place in spontaneous and unplanned social encounters in the community. The communicative strand of translanguaging (as opposed to those found in educational and transnational identity formation arenas) is located within and mediated by a different set 
of conversational circumstances that call for humility, empathy, accommodation and the need for intercalants to concede space for each other's linguistic systems.

However, notwithstanding these different contextual applications, all translanguaging theorists are united on one thing, which is this: in translanguaging, named languages do exist only insofar as they have social reality and not linguistic reality. There is very little, if anything at all, that is linguistic about named languages (García and Kleyn 2016). From a translanguaging perspective, the linguistic is located within the communicative systems of individual speakers who have the capacity to appropriately leverage their repertoires in ways that would enable them to perform according to social norms while simultaneously not being constrained by such norms. Thus, in spite of their differing contexts of applied interests, translanguaging theorists are united on the fact that linguistic resources or knowledge of multiple languages are part of a single language system that an individual uses to create meaning and accomplish goals (Daniel and Pacheco 2015).

So far so good-but a glaring problem still remains: to what extent has this body of quite contemporary scholarship pushed the boundaries of language research toward a new methodological direction that encourages the use of yet to be proven and anti-foundational methods? I address this question in the next section.

\section{Colonialism and contending methodological issues}

The tenuous foundation of logical positivism continues to exert an enormous influence in the social sciences (Baronov, 2004) and this includes sociolinguistics. It seems much of the burgeoning scholarship of this tradition is yet to break free from the conventional scientific method. There is tendency to do very little or no analysis of the underlying assumptions and beliefs that form the ideological presuppositions of widely used systematic research tools of the positivist tradition such as the questionnaire, surveys, oral interviews, focus groups and participant observations. These are often treated as if they were ideologically neutral and objective yet, as we know, they emerged out of specific contextual and cultural conditions in the Global North. The content and modus operandi of conventional methods are predominantly shaped by colonial understandings of what constitutes valid and legitimate knowledge (Ndhlovu 2017). The universalising tendencies of the conventional scientific method are regularly imposed on all societies (including those in the Global South) without due regard to contextual particularities. A major problem with adopting these conventional scientific methods holus bolus is that they also shape the nature of our research questions, what we look for or overlook in our data sets and, ultimately, our answers to such questions.

Four geopolitical assumptions that underpin the architecture of conventional methods have been suggested in the relevant social science literature (Peet 1997; Nustad 2004 and Connell 2007). First is the claim to universality whereby the very idea of mainstream research methods involves talking about universals and generalisations as if the whole world was a homogenous continuum. The fatalistic assumption of this claim is that "all societies are knowable in the same way and from the same point of view" (Connell 2007: 44). The second assumption is that of reading from the centre - the construction of a social world read through the eyes of the metropole and not through an analysis of the metropole's action on the rest of 
the world. What conventional scientific approaches overlook is the fact that the experiences of cultures and societies from other parts of the world cannot be fully understood through the use of methods that arose out of a colonial metropolitan reading of the world (Ndhlovu 2017). The third problem with conventional scientific methods is one about how they are underpinned by what Connell (2007) calls 'gestures of exclusion'. This is about the total absence or marginalisation of methodologies and theoretical frameworks from the non-Western and formerly colonised world in metropolitan texts on research. In those exceptional instances where material culture and ideas from these other parts of the world are acknowledged, they are rarely considered as part of the mainstream dialogue on research theory and method. Riding on the back of colonial ethnography and social anthropological frameworks emphasising the modern/ pre-modern distinction, the method of 'science' renders the cultures and thought processes from the Global South irrelevant and treats them as belonging to a world that has been surpassed (Connell 2007; Ndhlovu 2017). This leads us to the fourth contour, which has been termed 'grand erasure'. The point here is that when empirical knowledge and theorisation about humanity more generally are seen as coming solely from metropolitan society (where the roots of conventional research methods lie), the immediate effect "is erasure of the experience[s] of the majority of human kind from the foundations of social thought" (Connell 2007: 46).

All of the above put to question the claims of objectivity and neutrality that are often said to be the hallmarks of most of these scientific methods. For this reason, some humanities and social science scholars from across a range of disciplines have consistently called for breaking free from the conventional scientific method.
They include scholars who work under the banners of Southern Theory (Connell 2007; and Comaroff \& Comaroff 2011); Decolonial Epistemology (Mignolo 2002, 2011; Maldonado-Torres 2007; and many others); and Decolonising Indigenous Methodologies (Linda Tuhiwai Smith 2012; Bagele Chilisa 2011). Linda Smith (2012: i -xiv) in particular raises four pertinent points that undergird my line of argument:

- That we need to develop "counterpractices of research" relevant to the agenda of disrupting the current hegemonic rules of the research game.

- That we need to articulate research practices that arise out of the specificities of epistemology and methodology rooted in people's cultural experiences.

- That stories of research, examples of projects, critical examination, and mindful reflection must be woven together to make meaningful and practical designs.

- That we need new ways of knowing and discovering, and new ways to think about research in order to demonstrate the possibilities of reimagining research as an activity that can be pursued outside the narrow box of the scientific experimental design.

This is about integrating praxis, theory, action and reflection in ways that provoke revolutionary thinking about the roles of knowledge and knowledge production in social transformation. These methodological issues are not explicitly addressed in the frameworks of most contemporary sociolinguistic theories. I see this as a missed opportunity to integrate new and alternative methods more fully into language research. Therefore, I argue that in spite of their anti-conventional and anti-foundational stance, most researchers that have 
embraced contemporary theories of language (such as translanguaging), still submit to the use of the 'scientific method of enquiry.'

As I have already said in the introduction to this article, earlier and present generations of sociolinguists have made major advances in terms of generating new theoretical frameworks that challenge normativity and purism in language research. However, I do not think that it is good enough for us to simply come up with new conceptual frameworks that are not complemented by equally innovative methodological paradigms. I am guilty of this omission myself insofar as I have proffered new sociolinguistics theories such as 'the language nesting model (Ndhlovu 2013) and 'ignored lingualism' (Ndhlovu 2015) that are not supported by fresh and antifoundational methodologies. If we are indeed serious about pursuing this type of intellectual endeavour, we need to formulate counter-methodss of scientific enquiry that are consistent with the antifoundational premises of contemporary social science theories. In addition to the much broader humanities and social science scholarship cited above, some leading international applied linguists and sociolinguists such as Alastair Pennycook and Emi Otsuji (2010 \& 2015); Li Wei (2011) and Li Wei and Zhu Hua (2013) have articulated with greater clarity the call for methodological innovations in language research. Taking after Heller's (2011) notion of critical ethnographic sociolinguistics, Pennycook \& Otsuji (2015: 20) posit that we need to study contextually (ethnographically) the social use of language (sociolinguistics) with an eye to understanding relations of social differentiation and inequality. In discussing the methods that underpin their theory of 'metrolingualism', Pennycook \& Otsuji suggest the following about what we need to do in language research:
Ethnographic research [should] not only be about the gathering of data in specific contexts, the note-taking, the recording, the questioning, the observing, nor is it only about the writing, the attempts to capture what is going on, to describe the bustle of the market, the hectic work in the restaurant or kitchen, the interactions over lunch in a construction site. It is also about the conversations, the developing understandings as we sit and talk about the market gardens, watch conical hats in the fields and the plane flying overhead and try to make sense of all this. (Pennycook \& Otsuji, 2015: 44).

Drawing on their ethnographic work in metropolitan areas in Australia and Japan, Pennycook and Otsuji describe how the methodologies they used have sought to capture the "throwtogetherness of linguistic resources - across space and through different interactions and observing how resources come and go in one place - in order to relate physical activities of work, the social and historical trajectories of participants, the organisation of space and the language resources at play in particular places" ( $p$. 88). Along the same vein Li Wei (2011) pioneered the innovative method of moment analysis that is based on the idea that reflections of the critical moments often result in fundamental learning that enables individuals and groups to uncover or create knowledge from their own experiences for improving their future actions (p.1224). Lei Wei applied the method of moment analysis to a study that used a combination of observation of multilingual practices and metalanguage commentaries by three Chinese youths in Britain. He says "metalanguaging data can be collected through conversations, individual or group interviews, journals and autobiographies" (1225). Although 
moment analysis seems to still retain some footprints of the conventional scientific method, it takes a rather different turn by focusing on 'moments' of interaction. Thus, the data collection processes and procedures of moment analysis do not necessarily follow the sequential, systematic, directed and controlled approaches of the conventional scientific tradition.

This is precisely the methodological direction that the story of my encounter with Omphile is taking us. In the next section build on and extend the methodological innovations of this previous body of work by reviewing the framework of autoethnography as a possible explanatory paradigm for my empirical observations in the story I narrated above. Though it has been applied widely in other social science disciplines, autoethnography is rarely used as a method in language research. I describe below the insights of this approach and spotlight the promises it holds for a more innovative methodology of doing language research in ways that are in line with the anti-foundational stance of contemporary sociolinguistics theories.

\section{The case for autoethno- graphy}

The origins of autoethnography are traced to the 1980s, what Holt (2003: 18) calls the 'crisis of representation' period because this was a time when researchers were concerned about formalising qualitative research to be as 'rigorous' as quantitative research. Itwas also that point in history when qualitative researchers found themselves using diverse research strategies that were borrowed from the quantitative paradigm (Méndez 2013). Autoethnography, therefore, emerged as a response to this challenge and to increasing "calls to place greater emphasis on the ways in which the ethnographer interacts with the culture being researched" (Holt, 2003: 18). Steven Pace (2012:4) says the earliest uses of the term 'autoethnography' are found in a 1979 essay by cultural anthropologist Hayano who made a case for selfobservation in traditional ethnographic research. In more recent times, the term 'autoethnography' has come to be associated with the work of Carolyn Ellis (2004, 2007 \& 2009) and Arthur Bochner (1997, 2000, 2001 \& 2002). By way of definition, Ellis \& Bochner (2000: 739) say autoethnography is "an autobiographical genre of writing and research that displays multiple layers of consciousness, connecting the personal to the cultural." In a later publication, Ellis, Adams \& Bochner (2011) elaborate this definition further, noting that autoethnography expands and opens up a wider lens on the world in a manner that eschews rigid definitions of what constitutes meaningful and useful research. They posit that the autoethnographic approach "helps us understand how the kinds of people we claim, or are perceived to be, influence interpretations of what we study, how we study it and what we say about our topic" (Ellis, Adams \& Bochner 2011: 2). In their Handbook of Autoethnography, Jones, Adams \& Ellis (2013) provide an extended explanation of what autoethnography as method entails .

Autoethnography as method is about using unconventional ways of doing and presenting research. Some such non-conventional ways include the use of conversational styles of presentation that make the narration engaging and emotionally rich. As Ellis (2011:3) further advises " "Telling' is a writing style that works with 'showing' in that it provides readers some distance from the events described so that they might think about the events in a more abstract way. Adding some 'telling' to a story that 'shows' is 
an efficient way to convey information needed to appreciate what is going on, and a way to communicate information that does not necessitate the immediacy of dialogue and sensuous engagement." What this essentially means is that autoethnography provides room for the researcher/writer to use first-person to tell a story. This is especially powerful when the writer tells in an intimate way a story he/she observed or an interaction he/she participated in. It is precisely for this reason that I see the story of my encounter with Omphile as a good example of autoethnographic praxis in language research. Some of the subtleties of my interaction with Omphile that I have presented in this article might have been missed were it not for the first-person narrative style that enabled me to 'tell' and 'show' my eyewitness account in my own words. The firstperson narrative technique provided me with the opportunity to tell the story as I experienced it without waiting for others to express what I, as a researcherparticipant really wanted to be known and understood (Richards, 2008). To summarise, it is worth quoting Anderson (2006: 388) who says "the definitive feature of autoethnography is this valueadded quality of not only truthfully rendering the social world under investigation but also transcending that world through broader generalisation."

The main contours of autoethnography that set it apart from the procedures of mainstream experimental research designs are six-fold.

- The author of an autoethnographic research report usually writes in the first person style, thus making himself or herself an integral part of the object of research.

- Writing autoethnographically allows for the researcher's life to be studied along the lives of other participants in a reflexive connection. The researcher engages in analytic reflexivity, demonstrating an awareness of the reciprocal influence between him/herself, the setting and other participants (Chang, 2008). It is here that autoethnography aligns with the views of scholars who follow the tradition of reflexivity, which expresses "the inextricability of ordinary descriptions (such as typifications of persons, actions or situations) from the circumstances they describe, [whereby] the description and the circumstances are reciprocally-elaborative" (Watson 2005: 7).

- The accessibility of an autoethnographic writing style helps position the reader as an involved participant in the dialogue, rather than as a passive receiver (Pace, 2012).

- Autoethnography enables the researcher to demonstrate commitment to theoretical analysis while simultaneously capturing (in an accessible style of writing) what is going on in individual lives or sociocultural environments (Ellis, 2004).

- The richness of autoethnography is found in those realities that emerge from the interaction between the self and its own experiences that reflect the cultural and social context in which those events took place (Méndez, 2013: 284). On this point, the auto-ethnographic approach compares quite favourably with conversational analysis (CA), which "studies the organization of talk as situated, socially organized sets of practices ... as interactional structures that both shape the context in which they operate and enable its interactionally coordinated progression” ( Mazeland 2006: 156). As in autoethnography, the main focus in CA is on systematic practices such as overlap positioning and overlap resolution, collaborative turn construction, and the role of gaze, gesture and body positioning 
(Schegloff 2000, Lerner 1996, Mazeland 2006).

- The subjective interpretations that may arise from personal narratives oppose the positivist view of research which aims at presenting an 'objective' account of the truth. The personal and emotional involvement of the researcher in autoethnography thus counterbalances the rather distant and perceived 'objective' role of the researcher in a positivist stance (Méndez, 2013: 284).

Therefore, the distinct advantage of the method of autoethnography is that in addition to reporting about other participants, it also makes the researcher/narrator part of the research story. It engenders collaboration between the researcher-as-participant and other participants, thus levelling the power imbalances that characterise most conventional social science methods. In the context of my story with Omphile, autoethnography clearly doubles as a method for generating my empirical observations about our interaction, and as a framework for presenting the story and making sense out of it. The autoethnographic approach enabled me to construct a narrative that side steps the language of conventional ways of doing and thinking about research.

Like all other methods or conceptual frameworks, autoethnography has had its fair share of criticisms. Three such criticisms follow. First, autoethnography has been dismissed on perceptions of being insufficiently rigorous, theoretical, too aesthetic and emotional (Delamont 2009). Second, those scholars following the autoethnographic approach have been accused of doing too little fieldwork, observing too few cultural members, and not spending enough time with different others (Anderson 2006). The third criticism levelled against autoethnography is about how the researcher uses personal experience, hence supposedly biased data that does not fulfil scholarly obligations of hypothesizing, analysing and theorising (Ellis 2009; and Madison 2006). I see these criticisms as biased in the sense that they evaluate the utility of autoethnography using standards of the scientific experimental method. Autoethnography does not subscribe to the procedures and processes of conventional approaches. It is a totally different methodology that seeks to inaugurate 'an-other logic', 'an-other language' and 'an-other way' of doing research that has the potential to liberate social science research from the clutches of hegemonic conventionalism. I would argue that it is, in fact, these perceived limitations of autoethnography that hold the promise for doing research in ways that are in line with quite contemporary anti-foundational social science frameworks such as translanguaging, metrolingualism, and many others. The conceptual and methodological premises of autoethnography enable social scientists to ask big questions of small data (Salazar, Elliot \& Norum 2017), which clearly sets them apart from the conventional scientific method that is largely preoccupied with big data. I would argue that although research methodologies that are driven by big data are useful in certain contexts, they also tend hide more than they reveal - in some contexts - hence the need for approaches such as autoethnography that help us see the big picture out of small data. This way we get to see and learn more about the minute but quite significant human interest stories that often remain hidden in the masses of big data.

\section{Conclusion}

What I have done in this article is to extend the application of the insights of autoethnography by deploying them to 
explain the nature of human communication and linguistic usages in unplanned naturally-occurring encounters. I have also located the discussion within contemporary scholarly debates in sociolinguistics and related frameworks of reflexivity and conversational analysis as way to give my write-up the academic flavour that will, hopefully, make it resonate with the majority of target readers. There are at least four important points that can be gleaned from the story described and analysed in this paper. First, the moments of interaction and conversation that Omphile and I had from the very first point of contact through the mini-soccer game disprove - in very clear and unequivocal terms popular assumptions about the need to first establish the existence of a common code with our interlocutors prior to initiating a conversation. In naturallyoccurring human communication, the boundaries of named languages can be crossed without much recourse to deliberate bridging processes such as translation and interpretation. And, in the process of crossing language boundaries, we also simultaneously cross social boundaries and social distances. This creates opportunities for us to enter and experience each other's life-worlds, thus paving way for the establishment of common ground, thus ultimately leading to effective communication and mutual understanding.

Second, the willingness to participate in a common practice paves way for effective communication. The conversation between Omphile and I applied a transactive approach to language use whereby the deployment of our respective linguistic systems was an ongoing process of social transaction. This enabled us to recognise the "synergic network of plurilingual language use as a means to inspire trust in cross-cultural settings" (Khubchandani 1997: 37) as we played the soccer game as if we were old time friends. Therefore, what this story tells us is that speakers need ways of negotiating difference and converging on practices of mutual interest rather than negotiating codes that are shared with others. Such strategies of managing and accommodating linguistic difference without necessarily resorting to standard language ideological approaches teach us that communication always works (not in spite of) but because of rampant diversity of language practices (Ndhlovu 2015: 410).

The third take-home message is one about the centrality of humility, empathy and willingness to come down to the level of our interlocutors in establishing the common ground needed for effective communication to take place. Although Omphile and I had never met before, we were able to establish very good rapport and sustain our conversation not on the basis of a common linguistic code. Rather, our successful and productive interaction was sustained by our mutual willingness to accommodate each other's linguistic systems and social interests. Both of us were ready and willing to participate in a common social practice - the minisoccer match - which eventually saw us exist as a small community of practice with shared interests. Throughout our interaction our linguistic practices tended to fluctuate depending on our individual and collective evaluations of how our communication process was going. I, in particular, expanded and contracted my linguistic system at various stages during our interaction as a way to accommodate the developing linguistic system of a seven year old. The overall outcome was that both Omphile and I felt very comfortable in communicating and playing with each other.

The fourth point is this: although the conventional scientific method of positivism remains entrenched as the established way of doing research due to its perceived objectivity and 
neutrality, it has a dark side. The things that we know foundationally about the conventional method of science (research questions, research design, sampling techniques, and so on) are neither objective nor neutral. They are laden with subjective ideological presuppositions, assumptions and beliefs tied to contextual particularities and cultural specificities of those regions of the world from where they originated. In particular, the very close and intimate association of the positivist tradition of scientific enquiry with the rise and spread of colonial modernity means that many of its common sense assumptions need to be rethought. We need to re-think, for example, the supposed universal relevance of established approaches to research. The majority of them originated from the locality and particularism of social and cultural conditions of the Global North, and then generalised to all other societies - through colonial and other imperial processes - as if the whole world was a homogenous continuum.

Overall, the dynamic of linguistic usages that I 'show' and 'tell' in the story of my interaction with Omphile would have been missed if I were to follow the scientific method that emphasises conventionalism and systematicity. What we learn from the story I narrated and analysed in this article is that autoethnographic praxis of language research that is anti-establishment is possible - after all. It is possible to develop innovative methodologies that allow us to be specifically attentive of the small details of everyday life that present opportunities to ask big questions of small data.

\section{References}

Anderson, L. 2006. Analytic autoethnography. Journal of Contemporary Ethnography 35(4): 373-95.

Atkinson, J. M. \& Heritage, J. (eds.) 1984. Structures of Social action: Studies in Conversation Analysis. Cambridge: Cambridge University Press.

Baker, C. 2001. Foundations of Bilingual Education and Bilingualism, 3rd Edition. Clevedon: Multilingual Matters.

Baronov, D. 2004. Navigating the hidden assumptions of the introductory research methods text. Radical Pedagogy, $1-6$.

Blommaert, J. 2010. The Sociolinguistics of Globalization. Cambridge: Cambridge University Press.

Blommaert, J. et al. (eds) 2012. Dangerous Multilingualism: Northern Perspectives on Order, Purity and Normality. London: Palgrave Macmillan.

Bochner, A. P. 1997. It's about time: Narrative and the divided self. Qualitative Inquiry 3(4): 418-438.

Bochner, A. P. 2000. Criteria against ourselves. Qualitative Inquiry 6(2): 266-272.

Bochner, A. P. 2001. Narrative's virtues. Qualitative Inquiry, 7(2): 131-157.

Bochner, A. P. 2002. Perspectives on inquiry III: The moral of stories. In M. L. Knapp \& J. A. Daly (eds). Handbook of Interpersonal Communication (3rd ed.) Thousand Oaks, CA: Sage pp.73-101.

Brutt-Griffler, J. 2006. Language endangerment, the construction of indigenous languages and World English. In M. Pütz, J. A. Fishman \& J. N. Aertselaer (eds). Along the Routes to Power: Explorations of Empowerment through Language. Berlin and New York: Mouton de Gruyter pp. 35-54.

Canagarajah, S. 2011. Codemeshing in academic writing: Identifying teachable strategies of translanguaging. The Modern Language Journal 95(3): 401-417.

Canagarajah, S. 2013. Translingual Practice: Global Englishes and Cosmopolitan Relations. London and New York: Routledge.

Chang, H. 2008. Autoethnography as Method. Walnut Creek CA: Left Coast Press. 
Chilisa, B. 2011. Indigenous Research Methodologies. New York: Sage.

Colombo, M. 2003. Reflexivity and narratives in action research: A discursive approach. Forum: Qualitative Social Research 4(2) Available at http://www. qualitative-research.net/index.php/fqs/ article/view/718/1554.

Comaroff, J. \& Comaroff, J. L. 2011. Theory from the South: Or, how Euro-America is evolving toward Africa (The radical imagination). New York: Paradigm Publishers.

Connell, R. 2007. Southern Theory: The Global Dynamics of Knowledge in Social Science. Crows Nest: Allen \& Unwin.

Creese, A. and Blackledge, A. 2010. Translanguaging in the bilingual classroom: A pedagogy for learning and teaching? Modern Language Journal 94: 103-115.

Cummins, J. 1979. Linguistic interdependence and the educational development of bilingual children. Review of Educational Research 49: 222-251.

Cummins, J. 2007. Rethinking monolingual instructional strategies in multilingual classrooms. The Canadian Journal of Applied Linguistics 10(2): 221-240.

Czyzewski, M. 1994. Reflexivity of actors versus reflexivity of accounts. Theory, Culture and Society 11: 161-168.

Daniel, S. M. and Pacheco, M. B. 2015. Translanguaging practices and perspectives of four multilingual teens. Journal of Adolescent and Adult Literacy Available at doi: 10.1002/jaal500 accessed 11 September 2016.

Delamont, S. 2009. The only honest thing: Autoethnography, reflexivity and small crises in fieldwork. Ethnography and Education 4(1): 51-63.

Ellis, C. 2004. The Ethnographic I: A Methodological Novel about Autoethnography. Walnut Creek, CA: AltaMira Press.

Ellis, C. 2007. Telling secrets, revealing lives: Relational ethics in research with intimate others. Qualitative Enquiry 13: 3-29.

Ellis, C. 2009. Telling tales on neighbours: Ethics in two voices. International Review of Qualitative Research 2(1): 3-28.
Ellis, C., Adams, T. E. \& Bouchner, A. P. 2011. Autoethnography: An overview. Forum: Qualitative Social Research 21(1): Available at http://www.qualitativeresearch.net/index.php/fqs/article/ view/1589/3096

Ellis, C. \& Bochner, A. P. 2000. Autoethnography, personal narrative, reflexivity: Researcher as subject. In N. K. Denzin \& Y. S. Lincholn (Eds.). Handbook of Qualitative Research. Thousand Oaks: Sage Publications pp. 733-768.

Enfield, N. J. 2008. Common ground as a resource for social affiliation. In I. Kecskes \& J. L. Mey (Eds.). Intention, Common Ground and the Egocentric SpeakerHearer. Berlin/New York: Mouton de Gruyter pp. 223-54.

Errington, J. 2008. Linguistics in a Colonial World: A Story of Language, Meaning, and Power. Oxford: Blackwell.

García, O. 2009. Bilingual Education in the 21st Century: A Global Perspective. Malden MA \& Oxford: Wiley Blackwell.

García, O. and Li, W. 2013. Translanguaging: Language, Bilingualism and Education. Hampshire,: Palgrave Macmillan.

García, O. and Kleyn, T. 2016. Translanguaging theory in education. In O, García and T, Kleyn (eds). Translanguaging with Multilingual Students: Learning from Classroom Moments. New York \& London: Routledge pp. 9-33.

Giles, H. 1984. The dynamics of speech accommodation. International Journal of the Sociology of Language 46: 49-70.

Goffman, E. 1981. Forms of Talk. Philadelphia: University of Pennsylvania Press.

Gumperz, J. J. 1982. Language and Social Identity. London: Cambridge University Press.

Haugen, E .1972. The Ecology of Language. Stanford: Stanford University Press.

Harris, R. 1987. Language as social interaction: Integrationalism versus segregationalism. Language Sciences 9(2): 131-143.

Heller, M. 2011. Paths to Post-Nationalism: A Critical Ethnography of Language and Identity. Oxford, U.K.: Oxford University Press 
Heritage, J. 1995. Conversation analysis: Methodological aspects. In U. Quasthof (ed). Aspects of Oral Communication Berlin \& New York: Walter de Gruyter pp. 391-418.

Higgins, C. 2009. English as Local Language: Post-colonial Identities and Multilingual Practices. Bristol: Multilingual Matters.

Holt, N. L. 2003. Representation, legitimation and autoethnography: An autoethnographic writing story. International Journal of Qualitative Methods 2: 18-28.

Hornberger, N. H. \& Link, H. 2012. Translanguaging and transnational literacies in multilingual classrooms: A bilingual lens. International Journal of Bilingual Education and Bilingualism 15(3): 261-278.

Jacqemet, M. 2005. Transidiomatic practices: language and power in the age of globalization. www.sciencedirect.com/ science?_ob=ArticleURL\&_udi=B6VB64GFCR2T-1.

Jørgensen, J. N. 2008. Poly-Lingual Languaging around and among children and adolescents. International Journal of Multilingualism 5(3): 161-176

Jørgensen, J. N. 2010. Languaging. Nine years of poly-lingual development of young Turkish-Danish grade school students, vol. I-II'. Copenhagen Studies in Bilingualism, the Køge Series, vol. K15-K16. University of Copenhagen

Jones, S. H., Adams, T. E. \& Ellis, C. 2013. (Eds.) Handbook of Autoethnography. Walnut Creek, CA: Left Coast Press, Inc.

Khubchandani, L. 1997. Revisualising Boundaries: A Plurilingual Ethos. New Delhi and London: Sage.

Lerner, G. 1996. On the 'semi-permeable' character of grammatical units in conversation: Conditional entry into the turn space of another speaker. In E. Ochs, E. Schegloff \& S. Thompson (eds). Grammar in Interaction. Cambridge: Cambridge University Press pp. 238-276.

Li, W. 2011. Moment analysis and translanguaging space: Discursive construction of identities by multilingual Chinese youth in Britain. Journal of Pragmatics 43: 1222-1235.
Li, W. \& Zhu, H. 2013. Translanguaging identities: Creating transnational space through flexible multilingual practices amongst Chinese university students in the UK. Applied Linguistics 34(5): 516-535.

Madison, D. S. 2006. The dialogic performative in critical ethnography. Text and Performance Quarterly 26(4): 320-324.

Makoni, S. 1998. African languages as European scripts: The shaping of communal memory. In S. Nuttall \& C. Coetzee (eds). Negating the Past: The Making of Memory in South Africa. Oxford: Oxford University Press pp. 242-248.

Makoni, S. \& Pennycook, A. 2007. Disinventing and Reconstituting Languages Clevedon: Multilingual Matters.

Maldonado-Torres, N. 2007. On the coloniality of being and the geopolitics of knowledge: Modernity, empire, coloniality. City 8(1): 1-33.

Mazeland, H. Conversation analysis. Encyclopedia of Language and Linguistics 3: 153-162.

Méndez, M. 2013. Austoethnography as a research method: Advantages, limitations and criticisms. Colombia Applied Linguistics Journal 15(2): 279-287.

Mignolo, W. D. 2002. Geopolitics of knowledge and the colonial difference. South Atlantic Quarterly (101)1: 57-96.

Mignolo, W. D. 2011. Epistemic disobedience and the decolonial option: A manifesto. Transmodernity 1(2): 44-66.

Milroy, J. 2001. Language ideologies and the consequences of standardization. Journal of Sociolinguistics 5(4): 530-555.

Ndhlovu, F. 2010. Language politics in postcolonial Africa revisited: minority agency and language imposition. Language Matters 41(2): 21-38.

Ndhlovu, F. 2013. Language nesting, superdiversity and African diasporas in regional Australia. Australian Journal of Linguistics 33(4): 426-448.

Ndhlovu, F. 2015. Ignored lingualism: Another resource for overcoming the monolingual mindset in language education policy. Australian Journal of Linguistics 35(4): 398-414. 
Ndhlovu, F. 2017. Southern development discourse for Southern Africa: Linguistic and cultural imperatives. Journal of Multicultural Discourses 12 (2): 89-109. DOI: $10.1080 / 17447143.2016 .1277733$.

Nustad, K. G. 2004. The Development discourse in the multilateral system. In M. BØås \& D. McNeill (eds). Global institutions and development: Framing the world? London: Routledge pp. 13-23.

Otsuji, E. \& Pennycook, A. 2010.

Metrolingualism: Fixity, fluidity and language in flux. International Journal of Multilingualism 7: 240-254.

Pace, S. 2012. Writing the self into research: Using grounded theory analytic strategies in autoethnography. TEXT Journal http://www.textjournal.com.au/ speciss/issue 13/Pace.pdf

Peet, R. 1997. Social theory, postmodernism, and the critique of development. In $\mathrm{G}$. Benko \& U. Strohmayer (eds). Space and Social Theory: Interpreting Modernity and Postmodernity. Oxford: Blackwell pp. 72-87.

Pennycook, A. \& Otsuji, E. 2015. Metrolingualism: Language in the City. New York: Routledge.
Pennycook, A. 2010. Language as a Local Practice. London \& New York: Routledge.

Piccardo, E. 2013. Plurilingualism and curriculum design: Toward a synergic vision. TESOL Quarterly 47:600-614.

Richards, R. 2008. Writing the othered self: Autoethnography and the problem of objectification in writing about illness and disability. Qualitative Health Research 1: 1717-1728.

Salazar, N. B., Elliot, A. \& Roger, N. (eds) 2017. Methodologies of Mobility: Ethnography of Experiment. New York \& Oxford: Berghahn pp. 1-24.

Schegloff, E. 2000. Overlapping talk and the organization of turn-taking for conversation. Language in Society 29: 1-63.

Seidlhofer, B. 2003. Controversies in Applied Linguistics. Oxford: Oxford University Press.

Smith, L. T. 2012. Decolonizing Methodologies: Research and Indigenous Peoples. 2nd edition. London \& New York: Zed Books.

Watson, R. 2005. Reflexivity, description and the analysis of social settings. Ciências Sociais Unisinos 41(1): 5-10. 